\title{
媒介度に基づく道路ネットワークのコミュニティ 抽出法
}

\section{Community Extraction Method of Road Networks Based on Betweenness Con- tribution}

\author{
伏見 卓恭東京工科大学 \\ Takayasu Fushimi Tokyo University of Technology \\ fushimity@stf.teu.ac.jp \\ 斉藤 和巨 \\ 神奈川大学, 理化学研究所革新知能統合研究センター \\ Kanagawa University, Center for Advanced Intelligence Project, RIKEN \\ k-saito@kanagawa-u.ac.jp, kazumi.saito@riken.jp \\ 池田哲夫 \\ 静岡県立大学 \\ University of Shizuoka \\ t-ikeda@u-shizuoka-ken.ac.jp \\ 風間一洋和歌山大学 \\ Kazuhiro Kazama Wakayama University \\ kazama@wakayama-u.ac.jp
}

keywords: road network, group centrality, betweenness contribution, community extraction

\section{Summary}

In this study, we address the problem of detecting effective installation sites of signboards and identifying their influential zones for a given road network, under the setting that many residents can view them on their shortest paths to the destinations. To this end, based on a notion of group-betweenness centrality measure, we newly formalize this problem as a $k$-betweens problem and propose a community extraction method of road networks to identify the influential zones. In an existing method, the influential zone of each signboard is extracted by Voronoi tessellation against its installation site, which assumes that residents view the nearest signboard. In our proposed method, it is extracted by the proportion including the signboard on the shortest paths from the resident's departure point to various destinations. From experimental evaluations using artificial and real road networks, we confirmed that our method can extract effective installation sites of signboards such as intersection nodes near the entrance of the express highway, and their influential zones as communities according to the positional relationships with arterial roadways. Furthermore, by computing the degree of antagonism among communities using the entropy of betweenness contribution rates, we can quantify the effectiveness of installing the same signboards for residents of areas where the influential zones of multiple signboards overlap.

\section{1. は じめに}

家などの出発地から, 通勤・通学, 買い物, 旅行で目 的地に向かう際, 人々は道路に沿って, かつ, 可能な限 り最短の経路で移動する.この移動の際, 道路脇に設置 されている野立て看板を目にすることがある．看板設置 者の立場としては, 多くの人の目に触れる場所に看板を 設置することが望ましい，本研究では，道路網上を移動 する多くの人が閲覧するような効果的な看板配置場所を 求め，各看板の勢力圏を抽出することを試みる.

道路上あるいは地図上での看板配置に関する先行研究 として, 小山らはボロノイ分割に基づく手法を提案して いる [小山 15]. この研究では, 地図上での人々の移動を 考慮しユークリッド距離ではなくマンハッタン距離を採 用し, 看板配置場所を母点としたボロノイ分割を行うこ
とで各看板の勢力圏を抽出している．ボロノイ分割は最 も近くにある看板を閲覧するという行動モデルを前提と しているため，看板を見ることが目的となっているとも 言える.すなわち，看板配置の文脈においては適切な行 動モデルとは言えない. 本研究では, 目的地への最短経 路上で看板を閲覧することをモデル化するために，道路 ネットワークに対する媒介中心性の概念を導入する．提 案手法では，媒介中心性を拡張した指標により抽出した ノードを看板配置候補地とする，そして，各地域の住民 が最短経路で移動する際に最も多く閲覧する看板を計算 し，各看板を最も多く閲覧する地域を勢力圏（コミュニ ティ）として抽出する.

$$
\text { ネットワーク上のノードをいくつかのグループに分割 }
$$
する手法として, 様々なコミュニティ抽出手法, あるい 


\begin{tabular}{l||l|l}
\multicolumn{2}{c}{} & \multicolumn{2}{|l}{$\mathbf{k} 1$ 既存手法と提案手法の違い } \\
& 既存手法 & 提案手法 \\
\hline ノード間移動モデル & 特定ノード集合への移動 & 任意ノードペア間の移動 \\
対応する数理問題 & $k$-medoids & $k$-betweens \\
応用問題の例 & 避難所設置問題 & 看板配置問題 \\
抽出可能なコミュニティ & 近接地域分割 & 幹線道路分割
\end{tabular}

は，クラスタリング手法が提案されている．ネットワー クのリンク密度が比較的高い部分を抽出する手法 [Saito 09, Seidman 83] やリンクを切断していくつかの部分グ ラフに分割する手法 [Hagen 92, Shi 00] が代表的である. しかし，道路ネットワークは次数分布がベき乗則に従っ ていない, 最大次数が 10 未満である，隣接行列やラプラ シアン行列の固有值の差を表す Eigen-gap が極めて小さ いなど，一般の複雑ネットワークとは異なる性質を有し ているため，上述の手法を適用すると望ましい結果は得 られない. 一般的なデータに対するクラスタリング手法 として， $k$-means 法や $k$-medoids 法などが古くから用い られている。これらの手法をネットワークデータに適用 し，各ノードを最近傍にある代表ノードのクラスタに割 り振ることでコミュニティ抽出を実現できる.

著者らは，社会ネットワーク分析の一手法である近接 中心性の概念を拡張し，集合近接中心性を提案した。集 合近接中心性において $K$ 個の代表ノードを抽出すること は，ノード間距離をメトリックとした $k$-medoids 法にお けるメドイド集合を抽出することと等価である，そして， 各ノードを最も距離の近い代表ノードのコミュニティに 割り当てれば，ネットワーク上の $k$-medoids クラスタリ ングを実現できる．特に，道路ネットワークに対して集 合近接中心性の代表ノードを抽出することは, 避難所や コンビニ，病院などの施設配置問題を考えることになり， 実問題への応用にもつながる [武藤 11, 斉藤 10]. 従来手 法である $k$-medoids クラスタリングは, 避難所やコンビ 二などの施設の設置場所ノードを目的地とした移動をモ デル化している.したがって，各ノードにとって最も距 離の近い（近接度の高い）施設が目的地として選ばれる のが自然であり，近接地域分割によるコミュニティが抽 出される.すなわち, 各住民は自身から最も距離の近い 看板を閲覧することを想定した勢力圈が抽出される.

一方, 看板配置問題においては, 看板設置場所ノード が移動の目的地になることは考えにくい．任意の出発地 と目的地間の移動途中で，多く通過される（閲覧される） ノードが適切な看板設置場所と言える. 本研究では, 任 意のノードペア間の移動において，より多く通過される ノードを抽出する $k$-betweens 問題という数理問題を提 案する. $k$-betweens 問題における適切なノード集合を抽 出するために, 著者らの既存研究である集合媒介中心性 の概念，および，解法アルゴリズムを用いる [伏見 13]. 集合媒介中心性により抽出した $K$ 個の代表ノードを看 板配置候補地とし, 他のノードを最も媒介度の高い看板
（代表ノード）のクラスタに割り振ることで, 各看板の勢 力圈（コミュニティ）を抽出する手法を提案する. 提案 手法のベースとなる媒介中心性では, 任意のノードペア 間を最短経路で移動することを想定している．そのため， 提案手法を道路ネットワークに適用した場合, 高速道路 の入り口や幹線道路上のノードが看板設置候補地として 抽出されることが期待できる.すなわち, 各住民は様々 な目的地に向かう際に, 最も多く通過する経路上の看板 を閲覧することを想定した勢力圏が抽出される. 表 1 に, 従来手法と提案手法の違いをまとめた。本研究では, 両 手法を実験的に比較し, 提案手法の性質を評価する.

本論文は以下に示す構成である．2 章で提案手法に関 連する既存研究について整理し，3 章で提案手法の詳細 について説明する４ 4 章で評価実験に使用する実データ および比較手法について触れ，5章で実験結果について 議論する. 最後に本論文のまとめと今後の課題について 述べる.

\section{2. 関連 研 究}

本章では, 提案手法と既存手法の関連や相違点につい て整理する。

社会的ネットワーク分析のために, 幾つかの中心性指 標が提案されている [Freeman 79]. 他ノードへの距離に 着目し, 平均ノード間距離が小さいノードは重要である とする近接中心性や, 非連結なネットワークに対応する ために，他ノードへの距離の逆数を用いた調和中心性も 提案されている [Dekker 05]. 任意のノードペア間を仲介 する度合いに着目した媒介中心性や，それから派生した 中心性も多く提案されている [Brandes 08]. これらの中 心性指標を道路ネットワークに適用することで有用な知 見が得られている. Montis らは, 自治体をノード, 自治 体間の通勤者トラフィックを重み付きリンクとした多重無 向ネットワークを分析している [Montis 07]. 次数とクラ スタ係数の関係から自治体に階層性が存在すること, 中 心性指標と人口・富などに正の相関があることを示して いる. Park らは, 道路ネットワークに対して中心性指標 を適用し，そのエントロピーを計算することにより，住 宅街と繁華街などのトポロジー構造の違いを評価してい る [Park 10]. Crucitti らは, 交差点間の距離重みを考慮 した道路ネットワークを対象に 4 つの中心性指標の分布 を分析している. 中心性值分布のフィッティングパラメー タやジニ係数により, 類似道路構造をもつ地域を分類し 
ている [Crucitti 06]. このように, 道路ネットワークの分 析に関する研究では中心性が重要な役割を果たしている. 既存研究で用いられる中心性指標は, ネットワーク全体 に対する個々のノードの独立した性質を定量化したもの である．近隣ノードの影響の重複による過大評価を考慮 していないため, 近隣ノードの中心性スコアが類似した 值となる傾向にある. よって, 単純に既存中心性のスコ アが高いノードに着目すると，ネットワーク上の一部に 偏って位置するノードばかりが抽出され, 本研究の目的 である看板配置の候補地として適切でない。したがって， 本研究ではノード同士の依存関係を考慮して，ノード集 合の中心性スコアを定量化した集合中心性の概念を導入 する. そして, 抽出した代表ノードに基づいて, 全ノー ドを各代表ノードが影響を及ぼす領域に分割する。

代表ノードとの距離による分割, すなわち, $k$-medoids クラスタリングや提案手法における媒介度分割では，各 ノードと $K$ 個の代表ノードとの関係性により全ノードを 分割する. 最も関係が強い代表ノードのコミュニティに 割り当てられるが, 割り当てられなかった代表ノードと の関係が皆無というわけではない。したがって, 関係の強 さの比率を用いれば，重複コミュニティを抽出することも できる。ネットワークから重複コミュニティ（Oveerlapping Community）を抽出する手法として, Palla らの CP (Clique Percolation) 法, Kumpula らの SCP (Sequential Clique Percolation) 法, 風間らの SR（Spectral Relaxation）法がある [風間 07, Kumpula 08, Palla 05]. こ れらはいずれも, クリークなどの密な部分を繰り返し抽出 する際に, 各ノードが複数のコミュニティとして抽出され ることを許容している. Xie らの SLPA (Speaker-listener Label Propagation Algorithm) 法では, 半教師あり学習 の手法である Label Propagation を拡張して, 各ノードの ラベルをベクトルとして学習することで, ベクトルの次 元の值の比率によって重複コミュニティを抽出する $[\mathrm{Xie}$ 11]. 比率に着目する点で提案手法と類似しているが，媒 介度分割や近接度分割は代表ノードとの関係の強さの比 率を用いているのに対し, SLPA では隣接ノード間で類 似のラベルベクトルを有するように学習する点で大きく 異なる。

道路網上への施設配置問題, 看板配置問題に関する先 行研究として, Tabata らの研究と小山らの研究がある [小 山 15, Tabata 17]. Tabata らの手法では, 近接中心性に基 づくランキングで 1 位のノードを高速に計算し，そのノー ドを施設配置候補地としている。すなわち， $k$-medoids クラスタリングの貪欲法における第 1 代表ノードを高速 に求めている。一般的に, 複数施設を設置することでよ り多くのノード（住民）の需要に応えることができ，そ れぞれの施設が影響を与える領域を抽出することで設置 内容の戦略につながる. 本研究では, 1 つの候補地だけ でなく，他の選定済み候補地の場所を考慮して複数の候 補地を求め, さらにそれらの勢力圈を抽出する点で異な

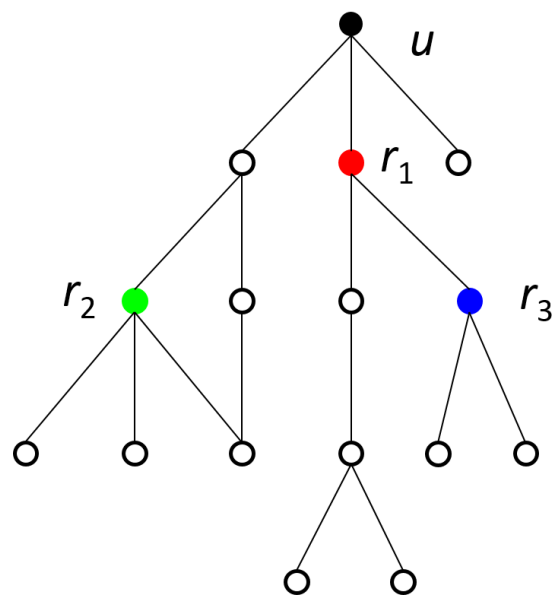

図 1 ノード $u$ を起点とした DAG 構造

る. 小山らの研究では, 配置済みの看板の勢力圏をマン ハッタン距離に基づくボロノイ分割により抽出している. これは，最短距離に位置する看板を閲覧することを前提 としている．前述したように，看板設置場所が移動の目 的地であることは稀であり，最短距離に位置する看板を 閲覧するというモデルには限界がある。通常は，任意の ノードペア間の移動途中で看板を閲覧するのが自然なモ デルである. したがって, 本研究では, 出発地から目的 地への最短経路において多くの人が通過する地点を看板 配置候補地とし，その移動に基づき勢力圏を抽出する.

\section{3. 提 案 手 法}

本研究では, 道路ネットワーク上に $K$ 個の看板を配 置し，それぞれの看板が影響を与えうる領域を抽出する 問題を扱う。ネットワーク上のあるノードを出発地，別 のノードを目的地とした際，任意のノードペア（出発地, 目的地) の最短経路に多数回含まれるノードは，多数の 移動者に閲覧されることが見込まれる。しかし，同一経 路上に多数の看板を設置すれば，一部の移動者のみに閲 覧され，他の地域の移動者に閲覧される機会が少なくな る. 本研究では，より多数の移動者に閲覧される看板配 置場所を求めるために，任意のノードペア間の最短経路 に多数回含まれるノードを抽出する問題を $k$-betweens 問 題として定式化し，集合媒介中心性と媒介度分割により 解を求める.

道路における交差点をノード，2つの交差点を結ぶ道 をリンクとした道路ネットワークを対象とする。すなわ ち， $N$ 個の交差点ノードの集合 $\mathcal{V}$ と $L$ 個のリンクの集合 $\mathcal{E}$ からなる無向の道路ネットワーク $G=(\mathcal{V}, \mathcal{E})$ を入力と する．与えられた道路ネットワークから，媒介中心性を 拡張した集合媒介中心性の領欲解法により $K$ 個の代表 ノード $\mathcal{R} \subset \mathcal{V}$ を看板配置場所の候補地として抽出する. そして，あるノードから他のノードへの最短経路におい て，代表ノードを通過する割合を各代表ノードの媒介度 
として定義し, 各ノードを最も媒介度の高い代表ノード のコミュニティに分割する，以下では，集合媒介中心性 の定義および計算法と媒介度分割について説明する.

\section{$3 \cdot 1$ 集合媒介中心性}

集合中心性は， $K$ 個のノードを選定する際，それらが 互いに協調して寄与することを考慮した中心性である. $K$ 個のノードを選んだ場合, 各ノードは互いに協調し影 響を及ぼしているため，一般的には集合としての中心性 スコアは，構成するノードの中心性スコアの単純な和と

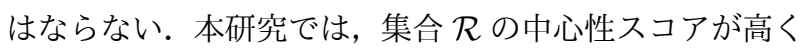
なるようにノードを選定する.

媒介中心性は, “任意のノードペア間のパスを媒介する 割合の高いノードは重要である”という概念に基づく指 標である。これを拡張した集合媒介中心性において，集 合 $\mathcal{R}$ の媒介度は $\mathcal{R}$ 内のノードの媒介度の単純な和では

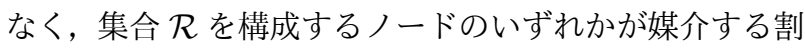
合（協調媒介度）の和により定義される. 集合 $\mathcal{R}$ の集合 媒介中心性 $\operatorname{setBWC}(\mathcal{R})$ は以下のように定義される：

$$
\operatorname{setBWC}(\mathcal{R})=\sum_{s \in \mathcal{V}} \sum_{t \in \mathcal{V}} \frac{\sigma_{s, t}(\mathcal{R})}{\sigma_{s, t}} .
$$

ここで, $\sigma_{s, t}$ はノード $s$ から $t$ への最短経路数であり, $\sigma_{s, t}(\mathcal{R})$ は, ノード $s$ からノード $t$ への最短経路で, 少 なくとも 1 つの $r \in \mathcal{R}$ を通る最短経路の数を意味する. 集合 $\mathcal{R}$ 内のノードのいずれかを通過するパス数により計

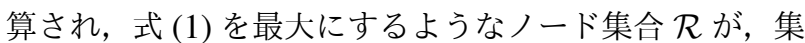
合としての媒介度が高いノード群である。 明らかに, 求 める集合の要素数 $K=|\mathcal{R}|=1$ のとき, 集合媒介中心性 により選定されるノードは，媒介中心性トップノードと 等しくなる．また，既存の媒介中心性上位のノードを選 定しても, それらが $s$ から $t$ までの同一パス上に多く存 在する場合，選定された個々のノードの貢献度は小さく， かならずしも協調媒介度を大きくするとは限らない。こ のような組み合わせ最適化問題は，一般に NP 完全クラ スに属し，対象が大規模になれば妥当な計算時間で厳密 解を求めることが困難となるが，式 (1) で定義される目 的関数がサブモジュラ性を有する．すなわち，比較的高 速な貪欲法による近似解が最悪ケースの解品質が保証さ れているため，領欲法により代表ノードを抽出する.

\section{$3 \cdot 2$ 媒介度分割}

上述した集合媒介中心性により $K$ 個の代表ノード $\mathcal{R} \subset$ Vを抽出し，以下で説明する媒介度により全ノードを $K$ 個のコミュニティに分割する。ノード $u$ を起点とした DAG（Directed Acyclic Graph）において，ノードuか ら他のノードへ向かう際に代表ノード $r_{k} \in \mathcal{R}$ を通過す る回数を代表ノード $r_{k}$ の媒介度 $z_{k}(u)$ として定義する. すなわち，DAGにおける自身を含めた子孫ノード数の合 計で計算できる。そして，ノード $u$ を最も媒介度が高い

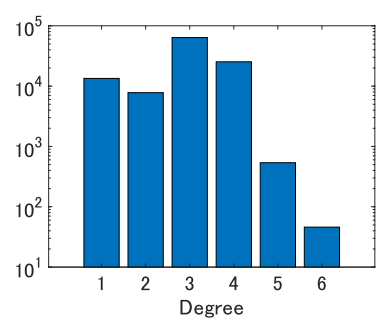

(a) Shizuoka

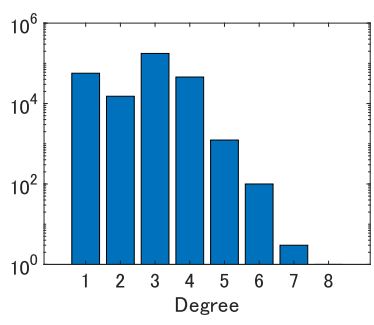

(b) Kanagawa
図 2 次数分布

代表ノードのコミュニティに割り当てる. 代表ノード $r_{k}$ に基づく媒介度分割によるコミュニティを以下のように 定義する：

$$
\mathcal{C}_{b w}(k)=\left\{u \in \mathcal{V} \mid \underset{1 \leq h \leq K}{\arg \max } z_{h}(u)=k\right\} .
$$

図 1 は,ノード $u$ を起点とした DAG と, DAG 上の 3 つの代表ノード $r_{1}, r_{2}, r_{3}$ を表している. 図 1 を見ると, $z_{1}(u)=8, z_{2}(u)=3.5, z_{3}(u)=3$ である. したがって, $u \in \mathcal{C}_{b w}(1)$ である.ここで, DAGにおける $r_{2}$ の子ノー ドは自分自身を含めて 4 ノードであるが，一番右側の子 ノードは親ノードが 2 つ存在し， $r_{2}$ を経由する確率は $1 / 2$ であるため, $z_{2}(u)=3.5$ となる.

\section{4. 評 価 実 験}

評価実験では，道路網を模して構築した人工ネットワー クと実際の道路網を用いて, 適切な看板配置候補地と各 看板の勢力圈を抽出できるかについて評価する. 本研究 の目的は, 任意の出発地と目的地間を最短経路で移動す る際，より多く通過されるようなノードを看板配置候補 地として抽出し, 各看板を多く通過する出発地ノード群 をその看板の勢力圏として抽出することである. よって, 高速道路の入り口や主要な幹線道路上のノードのように, 多くの人が通過するノードが抽出されるか, そして, こ れらの幹線道路の利用地域により勢力圏に分割できるか という観点で評価する.

\section{$4 \cdot 1$ データセット}

評価実験では，デジタル道路地図データ静岡県版と神 奈川県版より抽出した交差点をノード，道路をリンクと みなし構築したネットワークを用いる. Shizuoka ネット ワークのノード数は 110,925 , リンク数は 324,644 であ る. Kanagawa ネットワークのノード数は 259,151 , リン ク数は 805,152 である.これらのネットワークは規模こ そ異なるが先行研究 [Crucitti 06, Maulana 16] で用いら れたものと共通の特性を有する一般的な道路ネットワー クである. なお, 本研究で用いる既存手法と提案手法は, 対象ネットワークの規模に依存せず，使用したネットワー クょり小さな規模のデータに対しても類似の傾向の結果 が得られている。 
図 2 に両ネットワークの次数分布を示す.ただし, 縦 軸のみ対数スケールである. 図 2 を見ると, 次数分布が ベき乗則に従っておらず，一般的な道路ネットワークの 性質を有しているため, リンク密度に基づくコミュニティ 抽出手法は適用が困難であることがわかる.

\section{$4 \cdot 2$ 集合近接中心性と近接度分割}

比較に用いる手法として，近接中心性を拡張した集合 近接中心性により代表ノードを抽出し, 近接度（距離） に基づき分割する手法を採用する。すなわち，文献 [小 山 15] でも用いられている $k$-medoids 法である. 個々の ノードの近接度に注目する近接中心性の概念をノード集 合に対する概念に拡張すると，集合 $\mathcal{R}$ の近接度は $\mathcal{R}$ 内 のノードの近接度の単純な和ではなく, 集合 $\mathcal{R}$ 内の最も 近いノードいずれかとの距離 $\min _{r \in \mathcal{R}} d(u, r)$ （協調近接 度）を用いて定義される. 集合 $\mathcal{R}$ の集合近接中心性スコ ア $\operatorname{setCLC}(\mathcal{R})$ は以下のように定義される :

$$
\operatorname{setCLC}(\mathcal{R})=\sum_{u \in \mathcal{V} \backslash \mathcal{R}} \min _{r \in \mathcal{R}} d(u, r) .
$$

個々のノードに対する近接中心性，すなわち “他のノー ドとの距離が小さいノードは重要である”という概念の 自然な拡張となっている. 式 (2) を最小にするような集合 $\mathcal{R}$ を求める問題は, 各ノードと $K$ 個の代表ノードのう ち最小の距離となる代表ノードとの距離の和を最小にす る $k$-medoids 問題とみなすことができ, ネットワーク上 での施設配置問題の解法に有用と考えられる [斉藤 10]. また, 求める集合の要素数 $K=1$ のとき, 集合近接中心 性により選定されるノードは, 近接中心性トップノード と等しくなる. 本研究では, 提案手法と同様に, 貪欲法 により $K$ 個の代表ノードを抽出する．集合近接中心性 により $K$ 個の代表ノード $\mathcal{R} \subset \mathcal{V}$ を抽出し, 近接度によ り全ノードを $K$ 個のコミュニティに分割する（ボロノイ 分割) :

$$
\mathcal{C}_{c l}(k)=\left\{u \in \mathcal{V} \mid \underset{1 \leq h \leq K}{\arg \min } d\left(u, r_{h}\right)=k\right\} .
$$

これは, 最も距離の小さい, すなわち, 近接度の高い代 表ノードのコミュニティに割り当てている.

\section{5. 実 験 結 果}

\section{$5 \cdot 1$ 人エネットワークによる評価}

まず，媒介度分割と近接度分割の処理結果の違いを視 覚的にとらえるために, 図 3 に人工ネットワークに対し て $K=2$ で集合媒介中心性，集合近接中心性により代表 ノード (看板設置候補地) を求め, それぞれのコミュニ ティ（看板の勢力圏）を求めた結果を示す. 赤い星ノード が領欲法により最初に選ばれたノード, 緑の星ノードは 2 番目に選ばれたノードである。この人工ネットワークは, 2 つの都市間を 3 本の幹線道路でつないだ構造をしてい

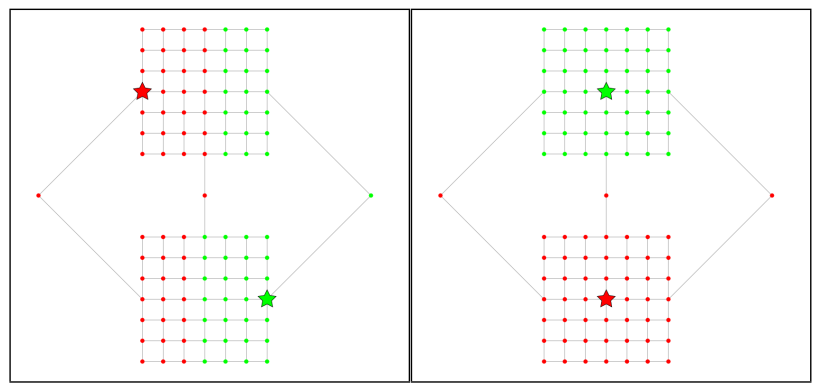

(a) 媒介度分割

(b) 近接度分割

図 3 人工ネットワークに対する処理結果

る. 3 つの幹線道路を用いることで, 高速道路のように短 いステップで他地域にたどり着くことができる．図 3(a) は，集合媒介中心性による代表ノードと媒介度分割によ るコミュニティの結果である. 抽出された代表ノードは, 高速道路のインターチェンジ（IC）に相当するノードで あると言える. IC は，最短経路で他ノードに向かう際に 多く通過する地点であり, その付近に野立て看板を設置 することで多くの住民が閲覧することが期待できる．各 代表ノードのコミュニティは，移動に際して通過する度 合いで分割されているため，異なる都市であっても同一 コミュニティに割り当てられている.つまり，最短経路で 他のノードへ向かう際，赤い地域の住民は緑の代表ノ一 ドと比較して赤い代表ノードをより多く利用することか ら，赤い代表ノードの勢力圏にあることを表している.

図 3(b) は，集合近接中心性による代表ノードと近接度 分割によるコミュニティの結果である. 抽出された代表 ノードは，各都市の中心街に相当するノードであると言 える. 中心街は, 他ノードへ短いステップでたどり着く ことができる地点である．各代表ノードのコミュニティ は, 代表ノードへ向かうに際してかかる距離の度合いで 分割されているため, 各都市がコミュニティとして抽出 されている.このように，人工ネットワークに対する処 理結果から，看板設置場所およびその勢力圏という観点 で見ると，集合近接中心性と近接度分割による結果は望 ましいものとは言えない.

\section{$5 \cdot 2$ 可視化による定性評価}

この節では, 抽出したコミュニティを可視化結果から 定性的に評価する．まず，対象ネットワークにおける主要 道路を図 4 に示す. Shizuoka ネットワークでは，東名高 速道路と新東名高速道路を利用することで，短いステッ プで他ノードへ移動することができる．Kanagawa ネッ トワークでは，横浜横須賀道路や小田原厚木道路などの 有料道路や保土ヶ谷バイパスを含む無料の主要道路を利 用することで，短いステップで他ノードへ移動すること ができる.

図 5 と図 6 に, Shizuoka ネットワークに対する処理 結果を示す．各可視化結果において，星印のノードは集 


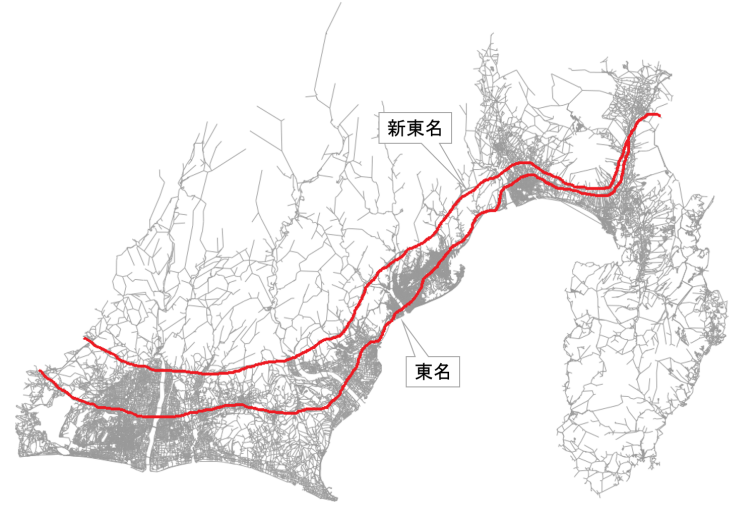

(a) Shizuoka ネットワーク

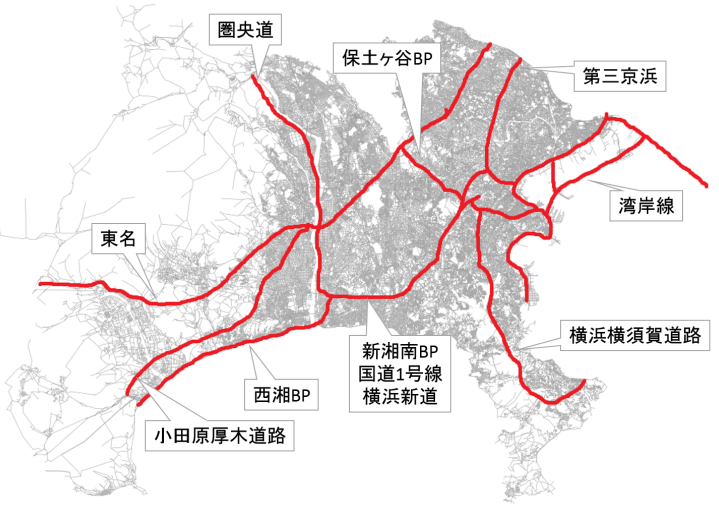

(b) Kanagawa ネットワーク

図 4 対象ネットワークにおける主要道路

合中心性により抽出した代表ノードであり，同色のノー ドは同一のコミュニティに割り振られたことを意味する. 図 5(a) と図 6 は，提案手法（集合媒介中心性・媒介度分 割）の結果である．代表ノードは，貪欲解法により選ば れた順に,

(1) 赤 : 新東名の藤枝岡部 IC 入口

(2) 緑 : 東名の焼津 IC 入口

(3) 青 : 新東名の新静岡 IC 入口

(4) 黄 : 東名の富士川スマート IC 入口

（5）桃：東名の袋井 IC 入口

である，人工ネットワークでの結果と同様に，主要道路 である高速道路の IC 付近のノードが選ばれている. 図 5(b) は，上記の代表ノードへのグラフ距離に基づき近接 度分割した結果であり，代表ノードが各コミュニティの 重心に位置している．図 5(a) の媒介度分割の結果は，代 表ノードを重心としたコミュニティを形成する近接度分 割の結果といくらか異なる．赤コミュニティに属する各 ノードは, 他のノードに最短経路で向かう際に，5つの代 表のうち赤の代表ノードを経由する割合が最も高いノー ドである．赤の代表ノードは Shizuoka ネットワークのほ ぼ中心に位置しており，かつ，高速道路の IC 入口付近の ノードであるため, 多くのノードペアを出発地・目的地と する最短経路において赤の代表ノードを経由する確率が 高い，県西部と中部においては，新東名を利用する地域 （赤）と東名を利用する地域（緑）の 2 つのコミュニティ におおよそ分割されている。県東部においては，新東名 や東名を利用する地域（青）と国道 1 号バイパスおよび 伊豆縦貫道を利用する地域（黄）におおよそ分割されて いる．また，人工ネットワークでの結果と同様に，青コ ミュニティのように離れた地域でも同一のコミュニティ に割り当てられている部分がある. 図 6 からわかるよう に，まず，東名と新東名を利用する地域に二分され，つ いで県東部も東名と国道 1 号・伊豆縦貫を利用する地域 に分割されていることがわかる.

図 5(c)，(d) は，集合近接中心性に基づく結果である. 代表ノードは，貪欲解法により選ばれた順に，
（1）赤：新東名の新静岡 IC 入口

(2) 緑 : 東名の浜松 IC 入口

（3）青 : 伊豆スカイラインの冷川 IC 入口

(4) 黄 : 浜松市国道 1 号線付近の交差点

(5) 桃: 静岡市国道 150 号線付近の交差点

である．主要な道路上のノードが選択されているが，集 合媒介中心性による代表ノードと異なる性質のノードが 抽出された。特に, 第 $3,4,5$ 代表ノードのように, 多く の人が通過するとは言い難いノードも含まれる。図 5(d) は, 上記の代表ノードへのグラフ距離に基づき近接度分 割した結果である. 図 5(b) と同様に，代表ノードを重心 としたコミュニティが形成されており，かつ，全体とし てバランスよく分割されている。一方, 図 5(c) は, 上記 の集合近接中心性による代表ノードに基づき媒介度分割 した結果であるが，代表ノード抽出と分割の方針が異な るため, コミュニティのバランスが良くなく, 解釈も困 難である.

図 7 と図 8 に, Kanagawa ネットワークに対する処理 結果を示す。図7(a) と図 8 は，提案手法（集合媒介中心 性・媒介度分割）の結果である。代表ノードは, 貪欲解 法により選ばれた順に，

（1）赤 : 第三京浜, 横浜新道, 首都高速（神奈川 3 号 三ツ沢線），国道 1 号線が交わる JCT 付近の交差点

(2) 緑: 新湘南バイパスと横浜新道をつなぐ国道 1 号 線上の交差点

（3）青 : 東名の横浜町田 IC 入口付近，および，東京環 状, 保土ヶ谷バイパスの接続点付近の交差点

（4）黄 : 狩場 (横浜横須賀道路が首都高速と分岐) IC 入口付近の交差点

（5）桃：圈央道の海老名 IC 入口 が抽出されている. 主要道路が交わる要所が代表ノード として抽出されている. 図7(a) は, 首都高速神奈川や湾 岸線, 第三京浜を利用する地域（赤）, 国道 1 号や横浜 新道, 小田原厚木道路を利用する地域 (緑), 東名を利用 する地域（青）, 横浜横須賀道路を利用する地域（黄）, 圏央道を利用する地域（桃）におおむね分割されている. 


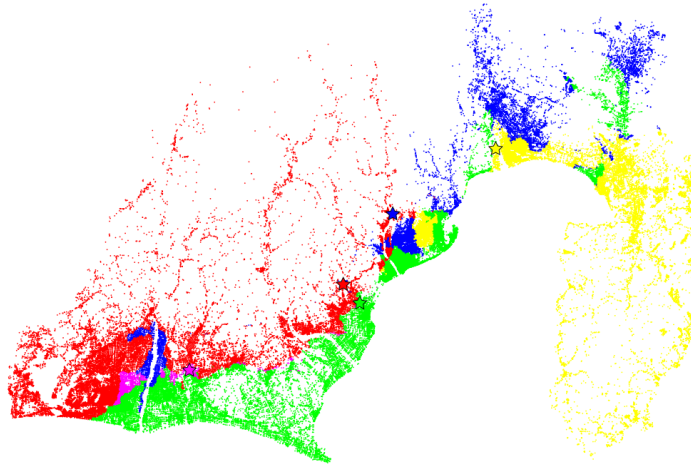

(a) 提案手法 : 集合媒介中心性 ·媒介度分割

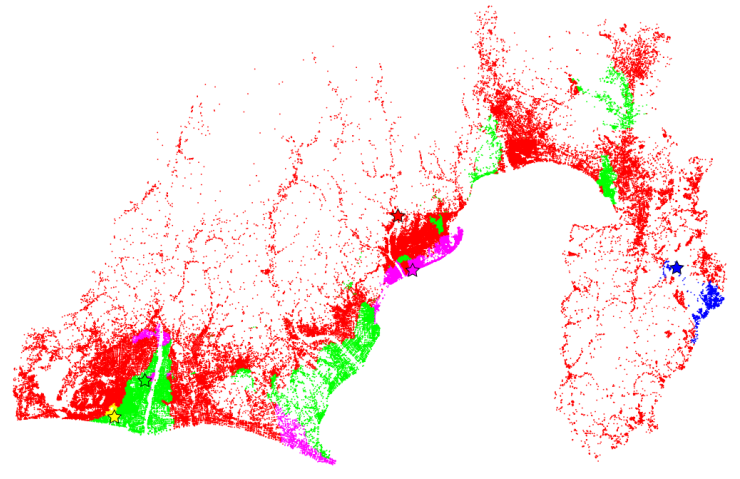

(c) 集合近接中心性・媒介度分割

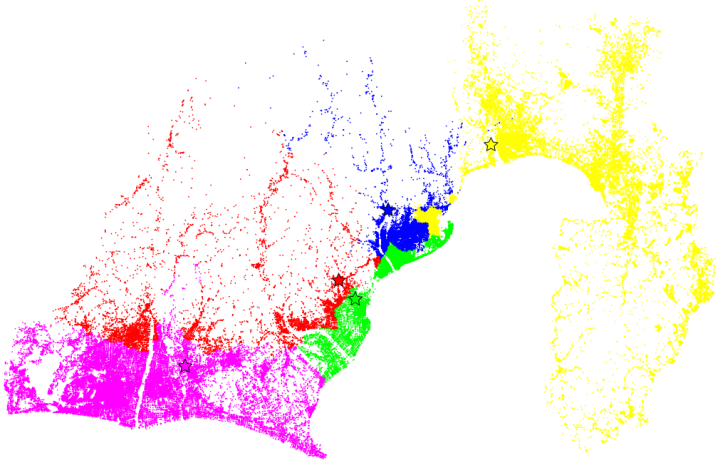

(b) 集合媒介中心性・近接度分割

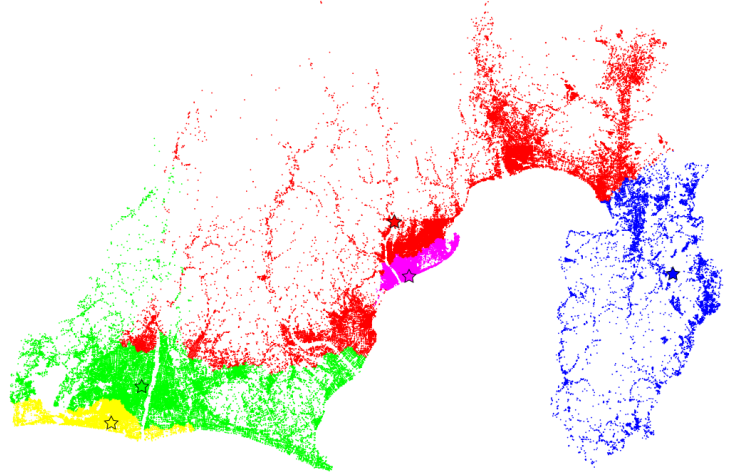

(d) 比較手法 : 集合近接中心性・近接度分割

図 5 Shizuoka ネットワークのコミュニティ抽出結果 $(K=5)$

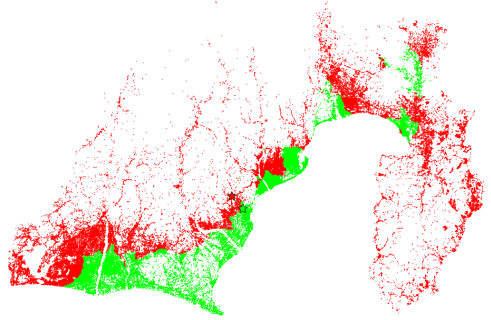

(a) $K=2$

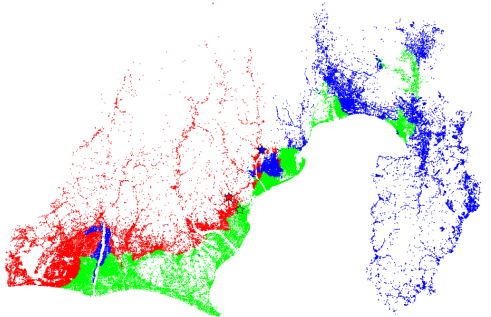

(b) $K=3$

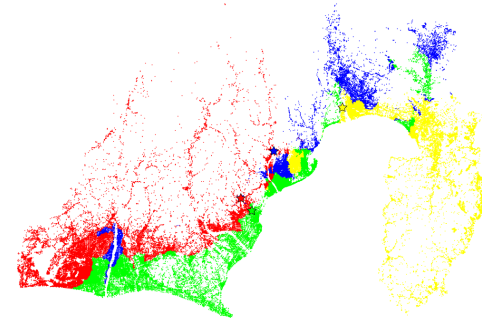

(c) $K=4$

図 6 提案手法におけるコミュニティ数の変化と抽出コミュニティ（Shizuoka）

さらに，図 8 を見ると，まず，東京方面へつながる主要 道路が通過するエリア（赤）と横浜市内の主要道路が通 過するエリア (緑) に分割している. つづいて，赤いエ リアを横浜を通過するエリア（赤）と横浜を通過しない エリア（青）に二分している，そして，緑のエリアを三 浦半島方面へ向かうエリア（黄）とその他のエリアに分 割している。

このように，2つの実道路ネットワークに対する処理結 果から, 提案手法は対象ネットワークを主要道路の利用 エリアにより分割し, 従来の距離に基づく分割法とは顕 著に異なるコミュニティを抽出することがわかった．近 接度分割では代表ノードを中心としたコミュニティが抽 出されるが，媒介度分割では代表ノードがコミュニティ の端，あるいは，複数のコミュニティの間に位置してい
ることがわかる．媒介度分割は，DAGにおける下流（あ るいは，上流）に位置する割合が多い代表ノードのコミュ ニティに割り当てられるためこのような結果となる.

\section{$5 \cdot 3$ 媒介度分割と近接度分割の違い}

この節では，同一の代表ノードに基づき媒介度分割と近 接度分割をした際のコミュニティ抽出結果の差異について 正規化相互情報量（Normalized Mutual Information）を用 いて定量的に評価する．媒介度分割により得られた $K$ 個 のコミュニティそれぞれに属するノード数の分布を $Q_{b w}=$ $\left[q_{b w}(1), \ldots, q_{b w}(K)\right], q_{b w}(k)=\left|\mathcal{C}_{b w}(k)\right| / N, \sum_{k=1}^{K} q_{b w}(k)=$ 1 とする. 同様に近接度分割によるノード数分布を $Q_{c l}$ とする. さらに，両分割手法による各コミュニティのノー ド数分布を $q(k, h)=\left|\mathcal{C}_{b w}(k) \cap \mathcal{C}_{c l}(h)\right| / N$ とする.この 


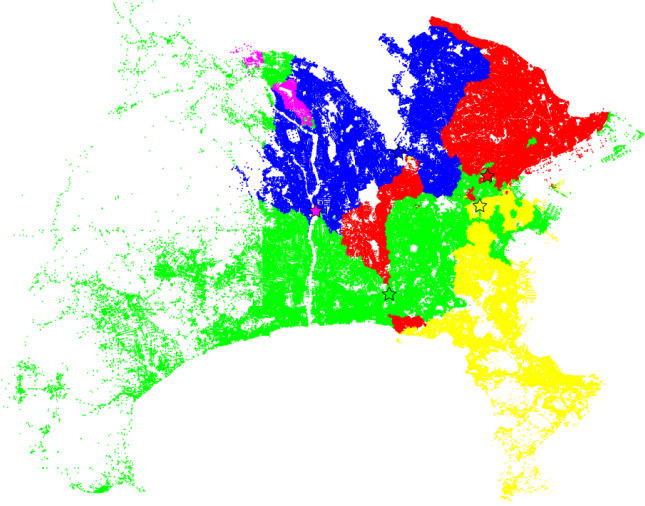

(a) 提案手法 : 集合媒介中心性 ·媒介度分割

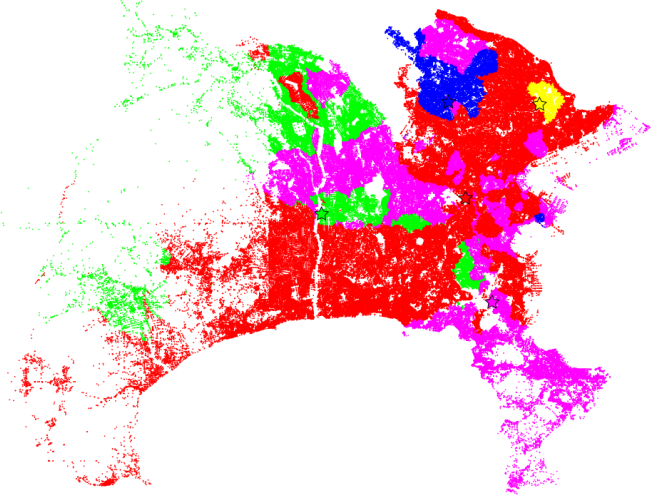

(c) 集合近接中心性 · 媒介度分割

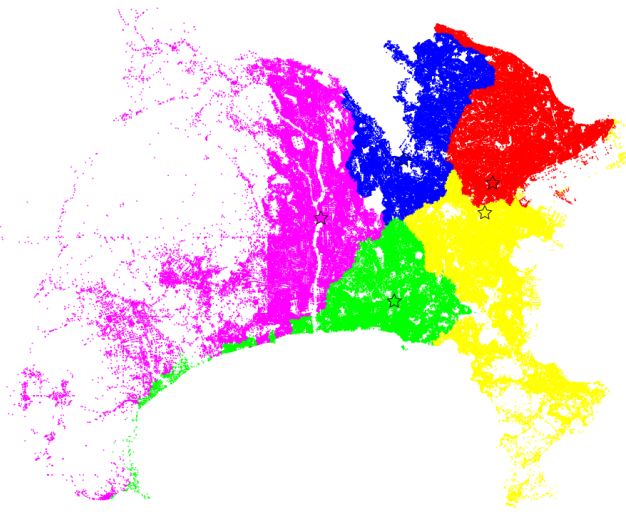

(b) 集合媒介中心性・近接度分割

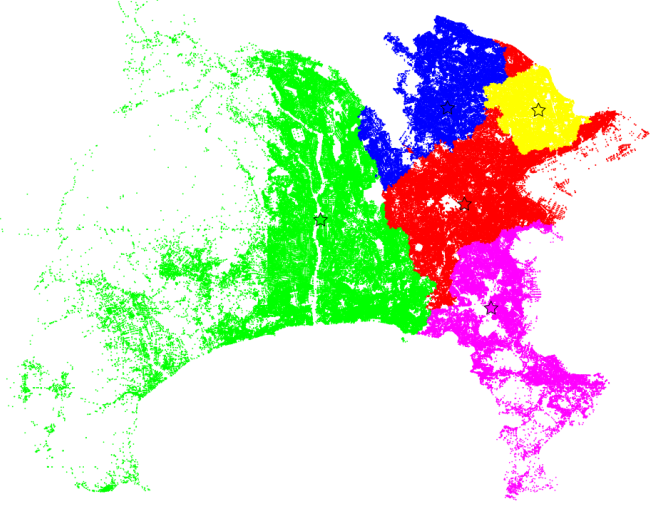

(d) 比較手法 : 集合近接中心性 ·近接度分割

図 7 Kanagawa ネットワークのコミュニティ抽出結果 $(K=5)$

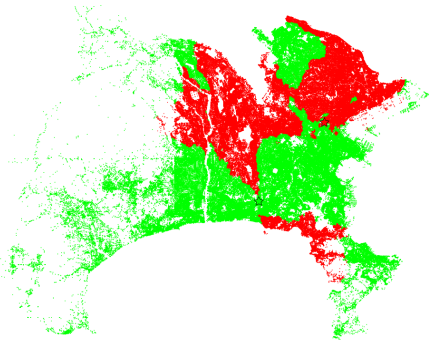

(a) $K=2$

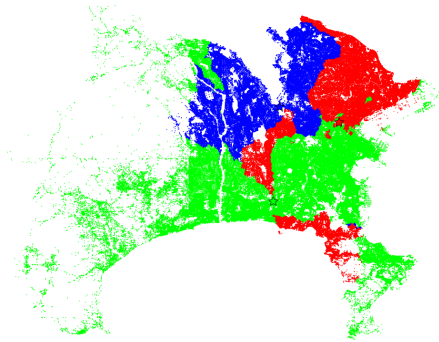

(b) $K=3$

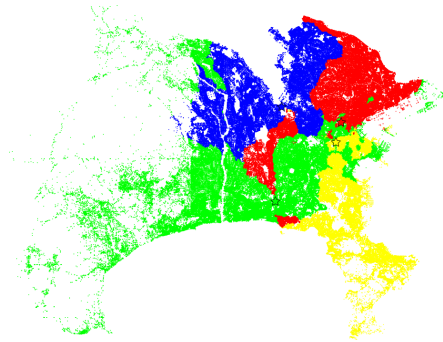

(c) $K=4$

図 8 提案手法におけるコミュニティ数の変化と抽出コミュニティ（Kanagawa）

時，これらの分布のエントロピーを

$$
\begin{gathered}
H_{b w}=-\sum_{k=1}^{K} q_{b w}(k) \log q_{b w}(k), \\
H_{c l}=-\sum_{k=1}^{K} q_{c l}(k) \log q_{c l}(k), \\
H=-\sum_{k=1}^{K} \sum_{h=1}^{K} q(k, h) \log q(k, h)
\end{gathered}
$$

とする.そして, NMI を以下のように計算する :

$$
N M I(b w, c l)=\frac{H_{b w}+H_{c l}-H}{\sqrt{H_{b w} * H_{c l}}} .
$$

この值が 1 に近いほど，コミュニティ抽出結果が似てい ることを意味する。図 9 は，横軸がコミュニティ数 $K$,
縦軸が媒介度分割と近接度分割によるコミュニティ抽出 結果の NMI を表す. 図中の赤線は集合媒介中心性によ る代表ノード, 青線は集合近接中心性による代表ノード を与えた際の両分割結果の NMI を示す. 図 9 を見ると, どちらのネットワークでも，集合媒介中心性による代表 ノードに基づくコミュニティ抽出結果の方が, 両分割手 法による結果が類似していることがわかる.さらに，コ ミュニティ数を大きくするにつれ, 結果が類似してくる傾 向にあるが, いずれの結果も NMI は 0.5 前後であり, や や類似する程度である.これらの結果からも，代表ノー ドへの距離に基づく分割と, 代表ノードを経由して辿り 着けるノード数に基づく分割では, 異なる性質を持つこ とがわかった。特に, 解釈可能なコミュニティを抽出で きる提案手法（集合媒介中心性 - 媒介度分割）は, 解釈 


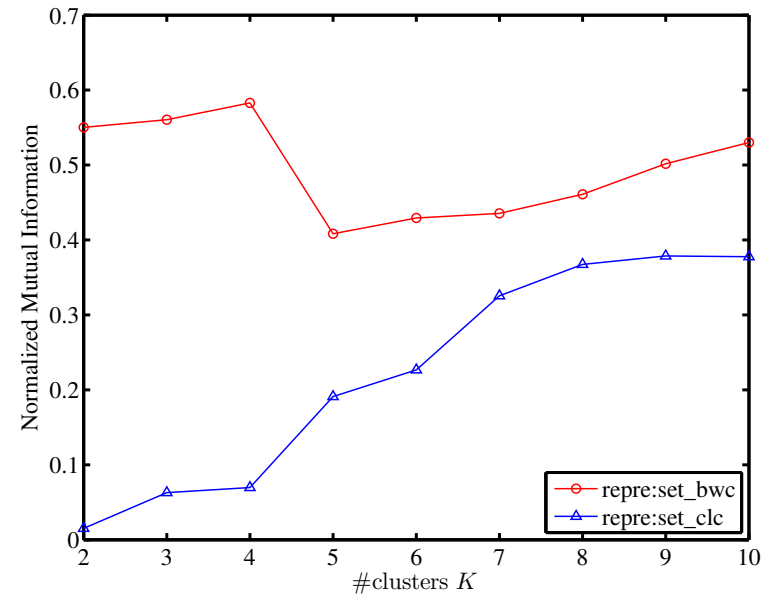

(a) Shizuoka

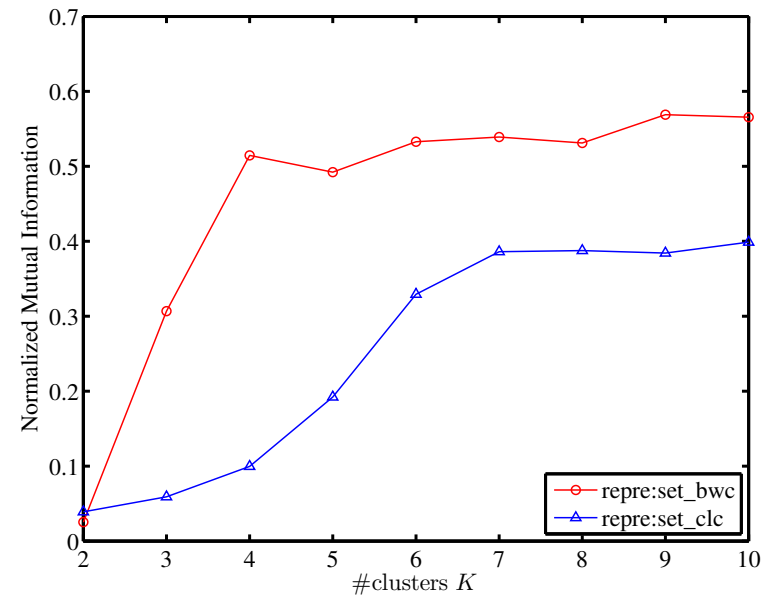

(b) Kanagawa

図 9 コミュニティ抽出結果の NMI

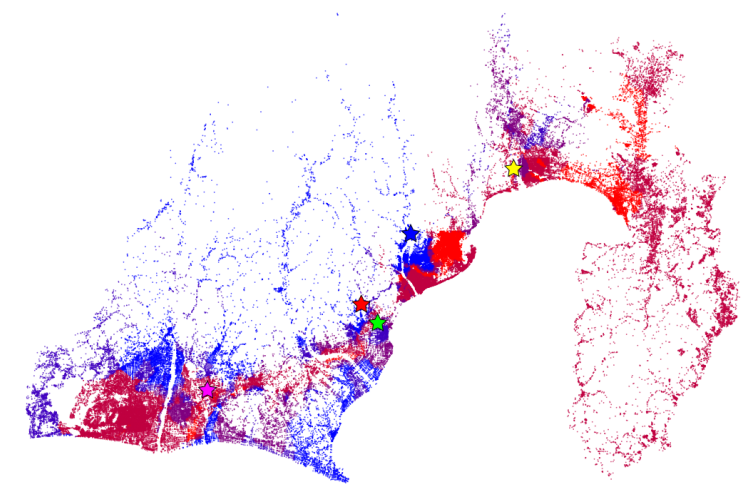

(a) Shizuoka

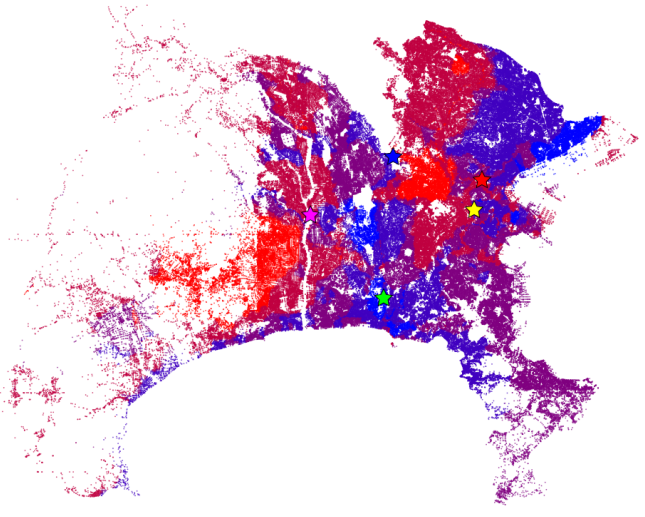

(b) Kanagawa

図 10 媒介寄与率のエントロピーヒートマップ

困難かつ不自然なコミュニティを抽出する集合近接中心 性・媒介度分割とは大きく異なる結果となった。

\section{$5 \cdot 4$ 媒介寄与率のエントロピー}

提案手法における媒介度分割は, 各ノードが他のノー ドへ最短経路で向かう際に経由する代表ノードを数え上 げ，その割合（媒介度）が最も高い代表ノードのコミュ ニティに分割するものである。この節では, 各ノードに 対して, ある代表ノードの媒介度だけ突出して大きいの か, あるいは, 複数の代表ノードの媒介度が拮抗してい るのかについて，エントロピーにより評価する。いま, ノード $u$ の代表ノード $r_{k}$ に対する媒介寄与率（媒介 度の割合）を $p_{u}(k)=z_{k}(u) / \sum_{h=1}^{K} z_{h}(u)$ とする.ノー ド $u$ に関する $K$ 個の代表ノードへの媒介寄与率分布を $P_{u}=\left[p_{u}(1), \ldots, p_{u}(K)\right]$ とし，そのエントロピー $H_{u}=$ $-\sum_{k=1}^{K} p_{u}(k) \log p_{u}(k)$ と計算する.

図 10 に, 両ネットワークにおける各ノードのエントロ ピーヒートマップを示す. エントロピーの值を赤から青 のグラデーションで表しており, 赤いノードほどエント ロピーが高く, 複数の代表ノードに対する媒介寄与率が 拮抗していることを意味する. 青いノードほどエントロ
ピーが低く，単一の代表ノードに対する媒介寄与率が突 出して高いことを意味する. Shizuoka ネットワークでは, 東名と新東名の 2 本の高速道路の狭間に横長に位置する 領域や静岡市清水区が赤くグラデーションされ, 高いエ ントロピーを示している。 この地域は, 複数の代表ノー ドに対する媒介寄与率が拮抗しており, すなわち, 複数の 看板の勢力圏が重複している領域であると言える. 特に, 清水区には東名と新東名をつなぐジャンクションがあり， いずれの高速道路をも利用することが可能であり，それ らの IC にある代表ノードを同程度に通過すると考えられ る.さらに，伊豆半島のエントロピーがやや高い值を示 しているが，5 つ代表ノードに対する媒介寄与率がいず れも低く拮抗している．逆に，山間部などの主要道路か ら離れた地域のノードは青にグラデーションされ，ある 特定の代表ノードの媒介寄与率が高い，すなわち，特定 の代表ノードに設置する看板のみを閲覧する確率が高い ことを示している. Kanagawa ネットワークでは, 東名と 小田原厚木道路に挟まれている県西エリア，東名と第三 京浜に挟まれている川崎市北西部および横浜北西部のエ リアが赤くグラデーションされ, 高いエントロピーを示 している．特に横浜町田エリアのノードは，川崎方面へ 
は第 1 代表ノード（図 7(a) で赤）, 県西方面へは第 2 代 表ノード（図 7(a)で緑），東京方面へは第 3 代表ノード (図 7(a) で青)，横浜方面へは第 4 代表ノード（図 7(a)で 黄），相模原方面へは第 5 代表ノード（図 7(a)で桃）を 経由するため, 複数の看板の勢力圏が重複している領域 であり，極めて高いエントロピーの值を示している.こ のように, 媒介寄与率のエントロピーを解析すると, 勢 力圏の重複度を知ることができる．候補地に同種の看板 を配置した場合，勢力圏が重複するエリアの住民は同種 の看板を何度も閲覧することになり，効率がよいとは言 えない.すなわち，媒介寄与率のエントロピーを用いて 勢力圏の重複度を計算することによって, 設置看板の内 容に関する戦略にもつながると期待できる.

\section{6. おわりに}

本研究では, 道路ネットワーク上への効果的な野立て 看板配置を目的に，媒介中心性を拡張した集合媒介中心 性により看板設置候補地を抽出し，媒介度分割により設 置した看板の勢力圏を表すコミュニティを抽出する手法 を提案した。実道路ネットワークを用いた評価実験によ り，従来の距離に基づくボロノイ分割による手法と比較 して，異なる性質のコミュニティを抽出できることを確 認した。抽出したコミュニティは対象ネットワークにお ける主要道路との位置関係に起因することを，可視化と 媒介寄与率のエントロピーにより確認した。すなわち， 人々が主要道路を利用した最短経路で目的地に向かう際 に閲覧するような看板配置場所および勢力圏が抽出でき ることを確認した。

今後は，ネットワーク内の全ノードへの最短経路では なく，ある程度の範囲内のノードを目的地とした場合の 媒介度分割や住宅地エリアを出発地, 商業エリアを目的 地とするような確率を導入したモデルを考慮する必要が あると考えられる.

\section{謝辞}

本研究は，JSPS 科研費（No.17H01826）の助成を受け たものである.

\section{$\diamond$ 参 考 文 献 $\diamond$}

[Brandes 08] Brandes, U.: On variants of shortest-path betweenness centrality and their generic computation, Social Networks, Vol. 30, No. 2, pp. 136 - 145 (2008)

[Crucitti 06] Crucitti, P., Latora, V., and Porta, S.: Centrality measures in spatial networks of urban streets, Physical Review E, Vol. 73, No. 3, p. 036125+ (2006)

[Dekker 05] Dekker, A.: Conceptual distance in social network analysis, Journal of Social Structure, Vol. 6, (2005)

[Freeman 79] Freeman, L.: Centrality in social networks: Conceptual clarification, Social Networks, Vol. 1, No. 3, pp. 215-239 (1979)

[伏見 13] 伏見 卓恭, 斉藤 和巳, 池田 哲夫, 武藤 伸明 : ノード群の 協調的振舞いに着目した集合媒介中心性の提案と応用, 電子情報 通信学会和文論文誌 D, Vol. J96-D, No. 5, pp. 1158-1165 (2013)
[Hagen 92] Hagen, L. and Kahng, A. B.: New spectral methods for ratio cut partitioning and clustering, IEEE Transactions on ComputerAided Design of Integrated Circuits and Systems, Vol. 11, No. 9, pp. 1074-1085 (1992)

[風間 07] 風間一洋, 佐藤 進也, 斉藤 和巳, 山田 武士 : 人間関係の 重なりを持つコミュニティ構造の抽出 (特集ネットワークが創発 する知能), コンピュータソフトウェア, Vol. 24, No. 1, pp. 81-90 (2007-01-26)

[小山 15] 小山 雅明, 高橋 由樹, 椎塚久雄 : ボロノイ図を用いた 野立て看板のなわばりモデルの基礎的考察, 日本感性工学会論文 誌, Vol. 14, No. 1, pp. 239-247 (2015)

[Kumpula 08] Kumpula, J. M., Kivelä, M., Kaski, K., and Saramäki, J.: A sequential algorithm for fast clique percolation, Physical Review E, Vol. 78, No. 2, p. 026109+ (2008)

[Maulana 16] Maulana, A., Saito, K., Ikeda, T., Yuze, H., Watanabe, T., Okubo, S., and Mutoh, N.: Characterizing similarity structure of spatial networks based on degree mixing patterns, in Proceedings of the 30th IEEE International Conference on Advanced Information Networking and Applications, (AINA2016), pp. 9-16 (2016)

[Montis 07] Montis, D. A., Barthelemy, M., Chessa, A., and Vespignani, A.: The structure of interurban traffic: A weighted network analysis, Environment and Planning B: Planning and Design, Vol. 34, No. 5, pp. 905-924 (2007)

[武藤 11] 武藤 伸明, 斉藤 和巳, 池田 哲夫, 永田 大, 伏見 卓恭 : 遅 延評価導入による局所改善クラスタリング法の高速化, 情報処理 学会論文誌数理モデル化と応用, Vol. 4, No. 1, pp. 1-10 (2011)

[Palla 05] Palla, G., Derényi, I., Farkas, I., and Vicsek, T.: Uncovering the overlapping community structure of complex networks in nature and society, Nature, Vol. 435, pp. 814-818 (2005)

[Park 10] Park, K. and Yilmaz, A.: A social network analysis approach to analyze road networks, in Proceedings of the ASPRS Annual Conference 2010 (2010)

[Saito 09] Saito, K., Yamada, T., and Kazama, K.: The kdense method to extract communities from complex networks, in Zighed, T. S. R. Z., Djamel and Hacid, H. eds., Mining Complex Data, Vol. 165 of Studies in Computational Intelligence, pp. 243257, Springer, Berlin / Heidelberg (2009)

[斉藤 10] 斉藤 和巳, 武藤 伸明, 池田 哲夫, 入月 卓也, 永田 大, 伊 藤かの子 : 遅延評価導入による局所改善クラスタリング法の高 速化, 情報処理学会論文誌 数理モデル化と応用, Vol. 3, No. 1, pp. 62-72 (2010)

[Seidman 83] Seidman, S. B.: Network structure and minimum degree, Social Networks, Vol. 5, No. 3, pp. 269 - 287 (1983)

[Shi 00] Shi, J. and Malik, J.: Normalized cuts and image segmentation, IEEE Transactions on Pattern Analysis and Machine Intelligence, Vol. 22, No. 8, pp. 888-905 (2000)

[Tabata 17] Tabata, K., Nakamura, A., and Kudo, M.: An efficient approximate algorithm for the 1-median problem on a graph, IEICE Transactions on Information and Systems, Vol. E100.D, No. 5, pp. 994-1002 (2017)

[Xie 11] Xie, J., Szymanski, B. K., and Liu, X.: SLPA: Uncovering overlapping communities in social networks via a speaker-listener interaction dynamic process, CoRR, Vol. abs/1109.5720, (2011)

\section{〔担当委員 : 諏訪 博彦〕}

2019 年 1 月 7 日 受理

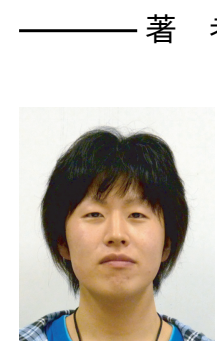

者紹介

伏見 卓恭 (正会員)

2014 年静岡県立大学大学院経営情報イノベーション研究 科博士後期課程修了. 同年, 静岡県立大学大学院経営情報 イノベーション研究科客員研究員. 2015 年筑波大学図書 館情報メディア系特別研究員. 2017 年東京工科大学コン ピュータサイエンス学部助教. 複雑ネットワーク, 可視化 の研究に従事. 博士 (学術). 情報処理学会, 日本データ ベース学会各会員. 


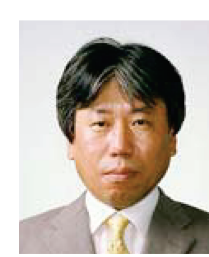

斉藤 和巳(正会員)

1985 年慶應義塾大学理工学部数理科学科卒業. 同年, 日 本電信電話株式会社入社. 2007 年静岡県立大学経営情報 学部教授. 2018 年神奈川大学理学部教授. 機械学習, 複 雑ネットワーク等の研究に従事. 博士 (工学). 情報処理 学会, 電子情報通信学会, 日本神経回路学会, 日本応用数 理学会, 日本行動計量学会, 日本データベース学会各会員.

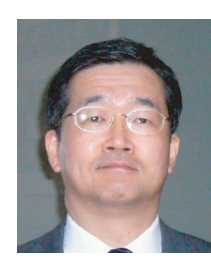

池田 哲夫(正会員)

1979 年東京大学理学部情報科学科卒業. 1981 年同大学院 理学系研究科情報科学専攻修了. 同年, 日本電信電話公社 （現 NTT）入社. 2002 年岩手県立大学ソフトウェア情報 学部教授. 2006 年静岡県立大学経営情報学部教授.デー タベース, 情報検索等の研究に従事. 博士 (工学) 。情報 処理学会, 電子情報通信学会, 日本データベース学会, 観光 情報学会各会員.

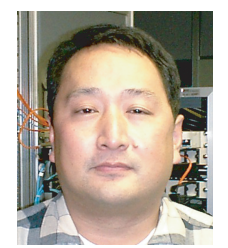

風間 一洋(正会員)

1988 年京都大学大学院工学研究科精密工学専攻修士課程 修了. 同年, 日本電信電話株式会社入社. 2005 年京都大学 大学院情報学研究科システム科学専攻博士課程修了. 2012 年和歌山大学システム工学部教授. Web 情報検索, Web マ イニングの研究に従事. 博士 (情報学). 日本ソフトウェ 了科学会, 日本データベース学会, ACM 各会員. 